\title{
En pasient i 20 -årene med icterus og smerter i ledd og muskler
}

\author{
Icterus og uvelhet fører ikke sjelden til innleggelse i sykehus. Årsakene \\ kan være mange. Her presenteres et sykdomsforløp med uventet etiologi.
}

En tidligere frisk person i 20-årene møtte opp på legevakten sent på kvelden med uvelhet og generelle muskel- og leddsmerter, som var kommet raskt i løpet av de siste dagene. Ved undersøkelse anga pasienten lett hoste og litt vondt i halsen samt luft $i$ magen, men ingen magesmerter. Pasienten fortalte at det to uker tidligere hadde vært smerter nederst i abdomen. En uke før legekontakten hadde pasienten kastet opp flere ganger, men dette var gått over før legevaktbesøket. Pasienten hadde ingen kjente allergier og brukte ingen faste medisiner.

På legevakten ble det ikke stilt noen diagnose, men det ble tatt blodprøver for at fastlegen kunne ta diagnostiseringen videre.

Blodprøvene viste ALAT på $989 \mathrm{U} / \mathrm{l}(10-70 \mathrm{U} /$ l), gammaglutamyltransferase (GT) $299 \mathrm{U} / \mathrm{l}$ (10-80 U/l) og ALP 143 U/l (35-105 U/l). Kreatinkinase (CK), elektrolytter, bilirubin, kreatinin, karbamid, urat og glukose var innenfor referanseområdet.

Pasienten gikk til fastlegen neste dag for oppfølging. Der ble det bemerket lett icterus $i$ conjunctiva. Funnet var dog usikkert, og blodprøvene viste normalt bilirubinnivå med $10 \mu \mathrm{mol} / \mathrm{l}(9-25 \mu \mathrm{mol} / \mathrm{l})$. ASAT var på dette tidspunktet $347 \mathrm{U} / \mathrm{l}$ (15-45 U/l). Hjerte, lunger og abdomen var uten anmerkninger, og det var normale tarmlyder.

Fastlegen valgte etter konferering å innlegge pasienten akutt i medisinsk avdeling på bakgrunn av mistanke om leversvikt.

På sykehuset ble det tatt en grundig anamnese. Det var ingen spesifikke arvelige sykdommer i familien, heller ingen usedvanlig yrkesmessig eller sosial eksponering, og pasienten hadde ikke vært i utlandet de siste to år. Pasienten hadde ikke brukt medisiner og misbrukte ikke alkohol. Pasienten hadde dog spist sushi kvelden før leddsmertene begynte.

Ved innkomst var undersøkelse av hjerte og lunger upåfallende, men det ble hørt en svak stenoselyd over høyre a. carotis. Pasienten hadde ikke feber. Leveren ble vurdert til å være lett forstørret, abdomen var ellers myk og uøm. Rektal eksplorasjon og hemofec var negativ. Det ble målt INR på 1,0 og albumin på $42 \mathrm{~g} / \mathrm{l}(36-45 \mathrm{~g} / \mathrm{l})$. Ferritinnivået var lett forhøyet på $472 \mu \mathrm{g} / \mathrm{l}$ (30-400 $\mu \mathrm{g} / \mathrm{l})$, dessuten var IgM-nivået lett forhøyet på 2,3 g/l (0,4-2,1 g/l). ASAT ble målt til 295 U/l (15-45 U/l) og laktatdehydrogenase (LD) til 244 U/l (105-205 U/l). Elektrolytter, blodgass og hematologi med leukocyttelling var normale.

Man fattet mistanke om en autoimmun hepatitt, på tross av den korte sykehistorien. For å avklare dette ble det tatt prøver for autoantistoffer. Dessuten måtte også infeksiøse og toksiske årsaker avklares.

Prøvene viste at det ikke var utslag på glattmuskelcelleantistoffene. Det var heller ikke utslag på ANA og antimitokondrieantistoffer, noe som taler imot en autoimmun hepatitt ldet ble spesifikt screenet for autoantistoffer av typene DNA, RNP, Sm, SSA, SSB, Scl-70, CENP-B, Jo-1, fibrillarin, RNA-polymerase III, Rib-P, PM-Scl, PCNA og Mi-2 for å utelukke autoimmun hepatitt, lupus erythematosus, systemisk sklerose, polymyositt og blandet bindevevssykdoml. Det var ikke forhøyet nivå av $\lg G, \lg A$, kobber eller jern. Det var heller ikke utslag på hepatitt $A$ hepatitt $B$-, hepatitt $C$ - og Epstein-Barrvirusprøvene. Det ble påvist cytomegalovirus- IgG, men ikke IgM, noe som taler for tidligere gjennomgått infeksjon.

Ved ultralydundersøkelse av abdomen hadde leveren normal størrelse, men det ble sett en mulig lett forhøyet leverekkogenisitet. Det ble ikke sett noen lesjoner, andre patologiske tegn eller parenkymskade i leveren.

Det ble således ikke funnet noen biokjemisk eller mikrobiologisk årsak til leverpåvirkningen. Klinisk ble pasienten vurdert til å være i bra form. Man mistenkte derfor andre årsaker til leversykdommen.

Pasienten brukte dog ingen medikamenter i perioden og hadde ikke inntatt store mengder alkohol. Pasienten kunne heller ikke angi noen andre eksponeringer som kunne forklare en toksisk hepatitt, bortsett fra det nevnte sushimåltidet. Det ble ikke testet for ytterligere forgiftninger.

Pasienten ble spontant bedre, var ikke ikterisk og ble utskrevet etter to dager. ALAT-

\author{
Alexander Løvdahl \\ al@sentrumlill.nhn.no \\ Tretten legekontor \\ og \\ Medisinsk avdeling \\ Lillehammer sykehus \\ og \\ Krankenhaus der Barmherzigen Schwestern \\ Ried im Innkreis \\ $\emptyset$ sterrike \\ Joakim Øverbø \\ Avdeling for virologi \\ Folkehelseinstituttet \\ > Se lederartikkel side 1604 \\ ब1 \\ Engelsk oversettelse på www.tidsskriftet.no
}


nivået var falt til 604 U/l (10-70 U/l) og laktatdehydrogenasenivået var også fallende.

Utskrivningsdiagnosen var uspesifisert toksisk leversykdom. Det ble antatt at pasienten kunne ha vært eksponert for et hepatotoksisk materiale som ikke kunne identifiseres nærmere. Pasienten ble satt opp til time på poliklinikken etter et par måneder. Øvrig oppfølging ble overlatt til fastlegen.

Hos fastlegen ble det tatt en kontroll av transaminasene en uke etter utskrivning. Prøven viste ytterligere bedring. Pasienten ønsket å få vite mer om årsaken til leversykdommen, og det ble avtalt en ny kontrolltime etter en måned. Pasient og fastlege søkte da sammen på internett og så igjennom mulige sykdommer, blant annet ved hjelp av Uptodate og Norsk Elektronisk Legehåndbok.

Noen av antistofftestene ble gjentatt for å utelukke feil på målingene. Det var fortsatt ikke utslag på autoantistoffene, men pasienten hadde selv funnet andre sykdommer som kunne utløse slike symptomer, blant annet hepatitt $E$.

Pasienten hadde ingen særlig kontakt med dyr. Selv om det ikke forelå noen sannsynlig smittevei, valgte fastlegen å ta en test for hepatitt $E$, som ble sendt til Folkehelseinstituttet. Denne prøven ble tatt to måneder etter at pasienten besøkte fastlegen første gang. Det ble påvist lgG og lgM mot hepatitt E-virus (HEV) $i$ to prøver med forskjellige reagenser. Det ble dog ikke påvist HEV-RNA ved PCR-analyse.

Ved telefonisk kontakt med Folkehelseinstituttet ble prøvesvarene bekreftet, og ut fra kliniske funn samt funn av antistoffer ble tilfellet således vurdert som en akutt infeksjon med hepatitt E-virus.

Pasienten var i etterkant av dette i god form og hadde ingen symptomer på sykdom.

\section{Diskusjon}

Hepatitt E er forårsaket av hepatitt E-viruset, et nakent enkelttrådet RNA-virus som normalt deles inn i fire genotyper med ulike karakteristika (1). Genotype 1 og genotype 2 opptrer i fattige land med dårlige sanitærforhold, og smitten skjer fekaloralt mellom mennesker. Sykdom med disse to genotypene opptrer både sporadisk og i store epidemier. De kjennetegnes av en usedvanlig høy mortalitet blant gravide på opp mot $25 \%$ (2).

I Europa dominerer genotype 3, som kan smitte en rekke ulike pattedyr, men hovedreservoaret ser ut til å være gris (1). Hepatitt E-smitte til mennesker i vår verdensdel skjer sannsynligvis i hovedsak via kontaminert mat og direkte kontakt med griseavføring, men smitte fra person til person via blodpro- dukter er også veldokumentert $(3,4)$. Inkubasjonstiden varierer fra to til åtte uker, med et gjennomsnitt på 40 dager (5).

Hos ellers friske mennesker forløper en hepatitt E-infeksjon som regel asymptomatisk. De som blir syke, har ofte milde og uspesifikke symptomer som varer fra et par dager til noen uker $(6,7)$, men alvorlige infeksjoner forekommer også (8). De vanligste symptomene er icterus, slapphet og feber (9). Det er ikke påvist økt dødelighet hos gravide ved smitte av genotype 3 (1), men den kan gi kronisk infeksjon hos immunsupprimerte og eksaserbasjon av eksisterende kronisk hepatitt, med potensielt alvorlige følger (5).

Det finnes ingen tall for prevalens eller insidens av hepatitt $\mathrm{E}$ i Norge, da det sjelden testes for sykdommen. Hepatitt E er en allmennfarlig smittsom sykdom som var nominativt meldingspliktig i MSIS i perioden 1991-2002. I hele perioden ble det bare meldt inn 24 tilfeller (10). I disse tilfellene var smitten overført i utlandet. I personlig kommunikasjon med Folkehelseinstituttet meldes det likevel om at det senere er registrert smittetilfeller der infeksjonen muligvis er overført innenlands.

I Europa varierer seroprevalenstall for anti-HEV-IgG i den generelle befolkningen fra $4,6 \%$ til $16 \%$ (1). I en studie ble det påvist HEV-IgG hos $9,3 \%$ av normalbefolkningen Sverige (11). Tallene er avhengig av alder, region, yrkesgruppe og valg av diagnostiske tester. Man kan få et inntrykk av insidensen av sykdommen ved å se på antallet HEVRNA-positive bloddonasjoner. Dette ble gjort i England i 2012-13, og det ble funnet hepatitt E-virus i $0,04 \%$ av 225000 testede bloddonasjoner. Infeksjonene som ble funnet var av genotype 3 (4).

Det finnes ingen godkjente legemidler mot hepatitt $\mathrm{E}$, men ribavarin og pegylert interferon er begge blitt fors $ø$ kt ved kroniske hepatitt E-infeksjoner hos immunsupprimerte - med lovende resultater (12). Det finnes ingen internasjonalt godkjente vaksiner mot sykdommen. Den kinesiskproduserte vaksinen Hecolin er vist å gi god beskyttelse mot genotype 4 (dominerende genotype i Kina), men effektiviteten mot de resterende genotypene er ikke bevist (13).

I det aktuelle tilfellet ble det bare påvist hepatitt E-virusantistoffer av typene IgG og IgM, det ble aldri påvist viremi ved PCR-analyse. Dette er ikke overraskende, siden viremien typisk er overstått i løpet av omtrent fem uker $(10)$ - og i denne pasienthistorien ble prøven først tatt omtrent to måneder etter innleggelsen.

Dette tilfellet er det eneste dokumenterte eksemplet på overføring av hepatitt E i Norge. Litteraturen på området kan dog tolkes slik at det er betydelige mørketall når det gjelder insidensen av hepatitt E i Europa (1).
Pasienten har gitt samtykke til at artikkelen blir publisert.

Vi takker Per Ove Hagestuen, kommuneoverlege i Ringebu, som har bistått ved revisjonen.

\section{Alexander Løvdahl (f. 1979)}

er fastlege, kommunelege og praksiskonsulent. Han er under utdanning til øre-nese-halsspesialist.

Forfatter har fylt ut ICMJE-skjemaet og oppgir ingen interessekonflikter.

\section{Joakim Øverbø (f. 1982)}

er lege i spesialisering i mikrobiologi. Han er medlem av styret for Norsk forening for medisinsk mikrobiologi.

Forfatter har fylt ut ICMJE-skjemaet og oppgir ingen interessekonflikter.

\section{Litteratur}

1. Kamar N, Dalton HR, Abravanel F et al. Hepatitis E virus infection. Clin Microbiol Rev 2014: 27: 116-38.

. Krain LJ, Nelson KE, Labrique AB. Host immune status and response to hepatitis $E$ virus infection. Clin Microbiol Rev 2014; 27: 139-65.

3. Van der Poel WH. Food and environmental routes of Hepatitis E virus transmission. Curr Opin Virol 2014: 4: 91-6.

4. Hewitt PE, ljaz S, Brailsford SR et al. Hepatitis E virus in blood components: a prevalence and transmission study in southeast England. Lancet 2014; 384: $1766-73$.

5. Sayed IM, Vercouter AS, Abdelwahab SF et al. Is hepatitis $E$ virus an emerging problem in industrialized countries? Hepatology 2015; 62: 1883-92.

6. Takahashi M, Tamura K, Hoshino Y et al. A nationwide survey of hepatitis $E$ virus infection in the general population of Japan. J Med Virol 2010; 82 271-81.

7. Renou C, Pariente A, Cadranel JF et al. Clinically silent forms may partly explain the rarity of acute cases of autochthonous genotype $3 \mathrm{c}$ hepatitis $\mathrm{E}$ infection in France. J Clin Virol 2011; 51: 139-41.

8. Aherfi S, Borentain P, Raissouni F et al. Liver transplantation for acute liver failure related to autochthonous genotype 3 hepatitis E virus infection. Clin Res Hepatol Gastroenterol 2014: 38 : 24-31.

9. Mansuy JM, Abravanel F, Miedouge M et al. Acute hepatitis $E$ in south-west France over a 5-year period. J Clin Virol 2009; 44: 74-7.

10. Blystad H. Hepatitt E-veileder for helsepersonell. Oslo: Folkehelseinstituttet, 2014. www.fhi.no/ artikler/?id=82752 (14.10.2015).

11. Olsen B, Axelsson-Olsson D, Thelin A et al. Unexpected high prevalence of IgG-antibodies to hepatitis $E$ virus in Swedish pig farmers and controls. Scand J Infect Dis 2006; 38: 55-8.

12. Kamar N, Abravanel F, Lhomme $\mathrm{S}$ et al. Hepatitis Evirus: chronic infection, extra-hepatic manifestations, and treatment. Clin Res Hepatol Gastroenterol 2015; 39: 20-7.

13. Teshale E, Ward JW. Making hepatitis E a vaccinepreventable disease. N Engl J Med 2015; 372: $899-901$

Mottatt 14.10. 2015, første revisjon innsendt 19.4 2016, godkjent 23.6. 2016. Redaktør: Liv-Ellen Vangsnes. 